Portland State University

PDXScholar

Environmental Science and Management

Faculty Publications and Presentations

7-14-2016

\title{
Variation in Tussock Architecture of the Invasive Cordgrass Spartina Densiflora along the Pacific Coast of North America
}

\author{
Jesus M. Castillo \\ Universidad de Sevilla \\ Brenda J. Grewall \\ USDA-ARS Exotic and Invasive Weeds Research Unit, University of California, Davis \\ Andrea Pickart \\ Humboldt Bay National Wildlife Refuge \\ Enrique Figueroa \\ Universidad de Sevilla \\ Mark D. Sytsma \\ Portland State University, sytsmam@pdx.edu \\ Follow this and additional works at: https://pdxscholar.library.pdx.edu/esm_fac \\ Part of the Earth Sciences Commons, and the Environmental Sciences Commons \\ Let us know how access to this document benefits you.
}

Citation Details

Castillo, J. M., Grewell, B. J., Pickart, A. J., Figueroa, E., \& Sytsma, M. (2016). Variation in tussock architecture of the invasive cordgrass Spartina densiflora along the Pacific Coast of North America. Biological Invasions, 18(8), 2159-2174

This Article is brought to you for free and open access. It has been accepted for inclusion in Environmental Science and Management Faculty Publications and Presentations by an authorized administrator of PDXScholar. Please contact us if we can make this document more accessible: pdxscholar@pdx.edu. 


\title{
Variation in tussock architecture of the invasive cordgrass Spartina densiflora along the Pacific Coast of North America
}

\author{
Jesús M. Castillo • Brenda J. Grewell • \\ Andrea J. Pickart • Enrique Figueroa • \\ Mark Sytsma
}

Received: 6 February 2015/ Accepted: 24 September 2015

(C) Springer International Publishing Switzerland 2016

\begin{abstract}
Some introduced species spread rapidly beyond their native range and into novel habitats mediated by a high degree of phenotypic plasticity and/or rapid evolutionary responses. In this context, clonality has been described as a significant factor contributing to invasiveness. We studied the abiotic environment and the responses of different tussock architecture traits of the invasive cordgrass Spartina densiflora Brongn. (Poaceae). A common garden experiment and field studies of S. densiflora in salt marshes across a wide latitudinal gradient from California (USA) to British Columbia (Canada) provided a model system for an integrated study of the potential mechanisms underlying the response of
\end{abstract}

Guest editors: Alan Gray and Malika Ainouche/Invasive Spartina.

J. M. Castillo $(\bowtie) \cdot$ E. Figueroa

Departamento de Biología Vegetal y Ecología,

Universidad de Sevilla, Seville, Spain

e-mail: manucas@us.es

B. J. Grewell

USDA-ARS Exotic and Invasive Weeds Research Unit, University of California, Davis, CA, USA

\section{A. J. Pickart}

U.S. Fish and Wildlife Service, Humboldt Bay National Wildlife Refuge, Arcata, CA, USA

\section{Sytsma}

Center for Lakes and Reservoirs, Portland State

University, Portland, OR, USA invasive $S$. densiflora populations to changes in environmental conditions. Our results showed that $S$. densiflora is able to adjust to widely variable climate (specifically, air temperature and the duration of the growing season) and sediment conditions (specifically, texture and hypoxia) through phenotypical plastic key functional tussock traits (e.g. shoot density, height, above- and below-ground biomass allocation patterns). Root biomass increased in coarser sediments in contrast to rhizomes, which were more abundant in finer sediments. Above-ground biomass and leaf area index increased mainly with air temperature during summer, and more robust (taller and wider) shoots were associated with more oxygenated sediments. In view of our results, $S$. densiflora appears to be a halophyte with a high degree of phenotypic plasticity that would enable it to respond successfully to changes in the abiotic conditions of salt marshes driven by global climate change, such as increasing salinity and temperatures.

Keywords Anoxia - Climate change - Invasive species $\cdot$ Phenotypic plasticity $\cdot$ Salt marshes $\cdot$ Tussock traits

\section{Introduction}

Some introduced species are able to spread rapidly beyond their native range and into novel habitats encompassing a wide range of environmental conditions. Two main mechanisms may explain this 
behavior: a high degree of phenotypic plasticity of the invading species, and/or rapid evolutionary responses by invasive populations (Gioria and Osborne 2014; Matesanz et al. 2010). Increased understanding of these two mechanisms would allow us to better identify environmental changes that promote invasiveness, predict future invasions, and manage existing invasions (Daehler and Strong 1996; Drenovsky et al. 2012).

The clonal growth strategy contributes to clonal plant dominance in many ecosystems and has been implicated as a significant factor contributing to invasiveness (Martina and von Ende 2013). Genets have been demonstrated to be locally adapted to their environment in terms of morphology (e.g. Prati and Schmid 2000) or to have environmentally based variation in functional traits (e.g. Roiloa et al. 2007). Therefore, determining intraspecific variations in tussock traits that shape clonal architecture, such as biomass distribution, shoot height and density and leaf area index (LAI) is essential to understanding the invasive capacity of clonal exotic plants.

The invasion of the halophytic South American cordgrass Spartina densiflora Brongn. (Poaceae) across a wide latitudinal gradient from California (USA) to British Columbia (Canada) provides a natural model system for an integrated study of the potential mechanisms underlying the response of invasive populations to substantial variation in climate and other environmental variables. S. densiflora is native to the South Atlantic coasts of Brazil and Argentina, where it occupies a wide variety of habitats from $23^{\circ} 20^{\prime} \mathrm{S}$ to $51^{\circ} 33^{\prime} \mathrm{S}$ latitude. S. densiflora has invaded salt marshes in Chile (ca. $33^{\circ} 30^{\prime} \mathrm{S}-42^{\circ} 46^{\prime} \mathrm{S}$ ), Morocco (ca. $34^{\circ} 50^{\prime} \mathrm{N}$ ), the southwest Iberian Peninsula (ca. $36^{\circ} 02^{\prime} \mathrm{N}-37^{\circ} 21^{\prime} \mathrm{N}$ ), and the Pacific Coast of North America from San Francisco Bay, California (ca. $37^{\circ} 56^{\prime} \mathrm{N}$ ) north to Vancouver Island, British Columbia (ca. $49^{\circ} 20^{\prime} \mathrm{N}$ ) (Bortolus 2006; Saarela 2012). Invasive populations of $S$. densiflora show a high degree of phenotypic plasticity in foliar traits along the Pacific Coast of North America (Castillo et al. 2014) and in characteristics of root systems in South America (Daleo and Iribarne 2009), probably related to the ancient hybrid origin of this species (Fortune et al. 2008). Furthermore, ecotypic differentiation related to environmental changes driven by latitude and elevation along the tidal gradient have been described for populations in its native range
(Álvarez et al. 2009; Di Bella et al. 2014), even though these native populations have low detectable genetic variation (Ayres et al. 2008). This low genetic variation may be even more accentuated, through the founder effect, for recently introduced $S$. densiflora invasive populations that are rapidly spreading along the Pacific Coast of North America through hydrochorous dispersal (Howard and Sytsma 2013). These populations are facing quite different abiotic conditions both in the atmospheric environment (e.g. changes in air temperature and growing season length) and in the sediment environment (e.g. variations in salinity and oxygenation levels) (Castillo et al. 2014).

We hypothesized that variation in tussock traits within populations of $S$. densiflora from a geographic gradient along the Pacific Coast of North America would primarily be due to phenotypic plasticity, rather than adaptive differentiation. To probe this hypothesis, we compared tussock traits from five populations at invaded field sites along the Pacific Coast with those populations grown in a common garden experiment. Integrated biogeographical approaches that include the study of natural populations along latitudinal gradients, paired with methods such as common garden experiments, are a way to increase our understanding of responses of plant species to environmental change (De Frenne et al. 2013), to understand exotic plant invasions (Hierro et al. 2005), and to test whether inter-population differences recorded in the field are due to genetic differentiation or phenotypic plasticity (Castillo et al. 2005a).

\section{Methods}

\section{Study sites}

Our field study was carried out in summer 2010 at five estuarine marshes invaded by Spartina densiflora along the Pacific Coast of North America. Our five study populations, fully described in Castillo et al. (2014), span the entire known latitudinal range of $S$. densiflora on this continent, and occur in a variety of estuarine environments including riverine, embayments, and sounds (FGDC 2012). The southernmost $S$. densiflora population evaluated was in San Francisco Bay at Corte Madera, California $\left(37^{\circ} 56^{\prime} 33^{\prime \prime} \mathrm{N}\right.$, $122^{\circ} 30^{\prime} 55^{\prime \prime} \mathrm{W}$ ) in a middle elevation salt marsh. At Humboldt Bay we studied the invasion of S. densiflora 
in a middle intertidal elevation marsh located in the northern portion of the bay $\left(40^{\circ} 49^{\prime} 53^{\prime \prime} \mathrm{N}\right.$, $\left.124^{\circ} 10^{\prime} 17^{\prime \prime} \mathrm{W}\right)$. Spicher and Josselyn (1985) speculated that this population was introduced to Humboldt Bay by ships from Chile that arrived for lumber trade during the late nineteenth century, and subsequently colonized $90 \%$ of the estuary's salt marshes (Pickart 2001). To the north of Humboldt Bay, our third study site was in the narrow, fringing intertidal zone of the Mad River estuary $\left(40^{\circ} 56^{\prime} 10^{\prime \prime} \mathrm{N}, 124^{\circ} 7^{\prime} 48^{\prime \prime} \mathrm{W}\right)$. On the Washington Coast, we included the invasive population first documented by Pfauth et al. (2007) at Grays Harbor Estuary $\left(46^{\circ} 57^{\prime} \mathrm{N}, 124^{\circ} 8^{\prime} 08^{\prime \prime} \mathrm{W}\right)$. The final population at our northernmost site was in a fringing salt marsh along the narrow Baynes Sound channel on the East Coast of Vancouver Island, British Columbia, Canada. This population, discovered in 2005 (Morgan and Sytsma 2010), occupies an intertidal cobble plain dominated by Salicornia pacifica (Standley) A. J. Scott $\left(49^{\circ} 33^{\prime \prime} \mathrm{N}, 124^{\circ} 52^{\prime} 09^{\prime \prime} \mathrm{W}\right)$.

The five population sites all experience mixed tides. The climate gradient ranges from Mediterranean in the south with cool, wet winters followed by hot, dry summers (but with summer fog), to maritime west coast climate with cooler, foggy summers for the other USA locations. At the northern extreme, the Vancouver Island site has a wider temperature range with lower low temperatures during winter but less summer fog than the other population sites. Mean daily yearround temperature varies between 9.7 and $17.7^{\circ} \mathrm{C}$ for San Francisco Bay, 8.8-14.8 ${ }^{\circ} \mathrm{C}$ for Humboldt Bay, 5.6-16.1 ${ }^{\circ} \mathrm{C}$ for Grays Harbor and $2.7-18.0^{\circ} \mathrm{C}$ for Vancouver Island (1971-2000 climate series data). Vancouver Island has the lowest mean minimum daily temperature among sites in January $\left(-0.8^{\circ} \mathrm{C}\right)$; mean temperatures have been similar for every location during June and July (ca. $11{ }^{\circ} \mathrm{C}$ ) (Environment Canada 2002; NCDC 2004).

\section{Spartina densiflora habitat evaluations}

We used hand-held GPS technology to record specific geographic coordinates for every population site. Meteorological conditions were characterized using mean daily temperature $\left({ }^{\circ} \mathrm{C}\right)$ for the week before our field evaluation visits as reported in local climatological stations (NCDC 2013). We acquired publically available data to characterize mean daily global horizontal insolation $\left(\mathrm{W} \mathrm{h} \mathrm{m}^{-2}\right.$ ) for the month (NREL
1992; NRC 2009), day-length (h) (Lammi 2008), and the number of annual growing degree days (reflecting both temperature and duration of the growing season) for all sites (Environment Canada 2002; NCDC 2004). We used $10^{\circ} \mathrm{C}$ as a threshold for growth of $S$. densiflora, which was applied previously for the congener Spartina alterniflora Loisel. (Kirwan et al. 2009). We obtained mean tidal level and range (m) for each location from NOAA Tide Predictions and Fisheries and Ocean Canada.

Spartina densiflora populations were visited during low-tides. Sediment redox potential (Eh) was determined in the field at ten random sampling points (portable meter, Orion $\mathrm{pH} / \mathrm{mV}$ 290A). Sediment cores (5 cm diameter, $0-10 \mathrm{~cm}$ depth) were collected, stored in sealed containers and transported to the laboratory. Sediment was mixed in a 1:1 ratio with distilled water to determine electrical conductivity (Hanna Instruments 9033) and $\mathrm{pH}$ (Orion $\mathrm{pH} / \mathrm{mV}$ 290A) ( $\mathrm{n}=10$ per site). Loss on ignition (LOI) was used to estimate sediment organic matter concentration $(\mathrm{n}=10)$. Gravel percentage was recorded gravimetrically in relation to the other sediment fractions. Percentages of sand, silt and clay were recorded using a hydrometer method ( $\mathrm{n}=3$ ) (Gee and Bauder 1986). Nitrogen concentration was measured on dried and ground sediments $(\mathrm{n}=10)$ using a Perkin Elmer 2400 CHN/O elemental analyzer (Waltham, MA, USA).

\section{Tussock traits}

Ten adult tussocks of Spartina densiflora with between 10 and 80 live shoots and a mean tussock area between 15 and $41 \mathrm{~cm}^{2}$ (ca. 2-3 years old) were randomly selected and individually marked in each of the five populations. Random samples were separated by a minimum of $1 \mathrm{~m}$ in an effort to sample potentially different genotypes. The following tussock traits were recorded for the marked tussocks in the field $(\mathrm{n}=10$ tussocks): (1) live, spiked, and dead shoot density; and (2) height and diameter of live shoots (5 randomly selected shoots per tussock). Shoot height was measured from the base of the shoot to the tip of the tallest leaf, and shoot diameter was recorded at the base of the shoot using calipers.

Ten entire tussocks, similar in size to those marked, were also collected from each population. Rhizomes and roots, which grew from rhizomes, were washed carefully to remove sediment. Biomass of roots, 
rhizomes, dead shoots with leaves, live shoots without leaves, and live and dead leaves of live shoots were recorded in the laboratory after drying samples in a forced-air oven at $80{ }^{\circ} \mathrm{C}$ for $48 \mathrm{~h}$. The dry weights (DW) of the different organs per plant $(n=10$ tussocks per population) were obtained, and total standing above-ground and below-ground biomass (AGB and BGB, respectively) and AGB:BGB ratio were calculated. Rhizomes were oven-dried, ground and then analyzed for total nonstructural carbohydrates (TNC; in $\mathrm{mg} \mathrm{g}^{-1} \mathrm{DW}$ ) using a modified procedure by Swank et al. (1982). TNC extracts were incubated at $55{ }^{\circ} \mathrm{C}$ for 15 min with one unit of amyloglucosidase (Sigma A-3042) per milliliter of completely hydrolyzed starch (Owens and Madsen 1998). The samples were assayed for reducing sugars using a photometric adaptation of the Somogyi method (Nelson 1944). In addition, LAI was obtained recording total leaf area and the area covered by each plant ( $\mathrm{n}=10$ tussocks). To calculate total leaf area per plant, we used the weight of five leaf drilled circular pieces with a known area $(0.5 \mathrm{~cm}$ diameter) and the recorded live leaf dry mass per plant (Carrión-Tacuri et al. 2011).

\section{Common garden experiment}

Every tussock of Spartina densiflora measured in the field study was collected and rhizomes were separated and grown in perlite substrate for 27 months (plastic pots: $20 \mathrm{~cm}$ diameter $\times 18 \mathrm{~cm}$ height) in a greenhouse at the University of Seville, Spain $\left(37^{\circ} 21^{\prime} 42^{\prime \prime} \mathrm{N}\right.$, $\left.5^{\circ} 59^{\prime} 15^{\prime \prime} \mathrm{W}\right)$. Pot bases were kept permanently flooded to a height of $2 \mathrm{~cm}$, and watered with $20 \%$ strength modified Hoagland's nutrient solution (Hoagland and Arnon 1950; Epstein 1972). Solutions were changed once a week. After 27 months of growth, every tussock trait recorded in the field, except belowground biomass, was recorded again for the same plants acclimated to common greenhouse conditions to assess if the differences observed in the field reflected phenotypic plasticity or population differentiation. Common greenhouse conditions included substrate Eh of $234 \pm 5 \mathrm{mV}, \mathrm{pH} 8.3 \pm 0.2$, electrical conductivity $0.5 \pm 0.0 \mathrm{mS} \mathrm{cm}{ }^{-1}$, mean monthly air temperature $23 \pm 2{ }^{\circ} \mathrm{C}$ and mean monthly air relative humidity $62 \pm 2 \%$. Light conditions of mean radiation of $700 \mu \mathrm{mol}$ photon $\mathrm{m}^{-2} \mathrm{~s}^{-1}$ at canopy level and a daily photoperiod of $16 \mathrm{~h}$ (that was extended with incandescent lights, Osram Vialox NAV-T (SON-T)
$400 \mathrm{~W}$, giving a continuum spectrum) were set up to imitate those recorded at higher latitude sites during summer in relation to photoperiod and light intensity. Spartina densiflora is a facultative halophyte that can germinate, establish, and develop in freshwater conditions (Nieva et al. 2001a; Castillo et al. 2005b). Fresh water was used to avoid salinity effects on tussock growth, since salinity has a significant effect on $S$. densiflora growth and biomass allocation (Grewell et al. 2015).

Data analyses

Statistical analyses were carried out using SPSS 12.0 (SPSS Inc., Chicago, USA). Deviations were calculated as standard error of the mean (SEM). Data were tested for homogeneity of variance and normality with the Levene test and the Kolmogorov-Smirnov Test, respectively $(P<0.05)$. When homogeneity of variance between groups was not found, data were transformed using $\ln (\mathrm{x})$ function. If homogeneity of variance was not achieved by data transformation, then the means were compared using Kruskal-Wallis H-test and Mann-Whitney U-test. Tussock traits were compared among $S$. densiflora populations by oneway analysis of variance (ANOVA) using the geographic location of populations as the grouping factor (F-test). Tukey's Honest Significant Difference (HSD) test between two means was calculated only if the F-test was significant at the 0.05 level of probability. Principal Components Analysis (PCA) was performed to reduce the number of abiotic and tussock trait variables in the field, analyzing the correlation matrix with 25 maximum iterations for convergence without rotation to extract independent PC factors with eigenvalues $>1$. Multiple linear regression analyses were used to characterize the relationships between PCA factors of the abiotic environment (A) with PCA factors of tussock traits $(\mathrm{T})$. Simple linear regression analyses were used to characterize the relationships between abiotic variables and tussock traits.

\section{Results}

Abiotic environment in the field

Four factors were obtained for the abiotic environment from the PCA, explaining $86.0 \%$ of the variance. The 
first factor (PC1-A) was positively correlated with latitude, day length (varying between $14 \mathrm{~h} 47^{\prime}$ at San Francisco Bay and $15 \mathrm{~h} 56^{\prime}$ at Vancouver Island), mean tidal level (changing between 0.96 and $1.67 \mathrm{~m}$ at San Francisco Bay and Vancouver Island, respectively) and coarse substrates (sediments with higher sand and gravel percentages and lower clay percentage), and negatively with the number of growing degree days (ranging from 924 for Vancouver Island and 3029 for San Francisco Bay). PC2-A was positively correlated with mean tidal range [minimum at San Francisco Bay (1.26 m) and maximum at Grays Harbor $(2.20 \mathrm{~m})$ ] and negatively with more anoxic (Eh between $-203 \pm 67 \mathrm{mV}$ at Grays Harbor and $+191 \pm 21 \mathrm{mV}$ at San Francisco Bay) and acidic sediments ( $\mathrm{pH}$ varied narrowly between $6.3 \pm 0.1$ at Grays Harbor and 7.2 \pm 0.1 at Vancouver Island) exposed to less mean daily isolation (ranging between $4964 \mathrm{~W} \mathrm{~h} \mathrm{~m}^{-2}$ at Grays Harbor and $6322 \mathrm{~W} \mathrm{~h} \mathrm{~m}^{-2}$ at San Francisco Bay). PC3-A was positively correlated with saltier sediments (electrical conductivities ranging from $0.2 \pm 0.0 \mathrm{mS} \mathrm{cm}^{-1}$ at Mad River and $13.8 \pm 0.7 \mathrm{mS} \mathrm{cm}^{-1}$ at San Francisco Bay) and mean daily temperature [minimum at Grays Harbor $\left(12.3{ }^{\circ} \mathrm{C}\right)$ and maximum at Vancouver Island $\left.\left(20.3{ }^{\circ} \mathrm{C}\right)\right]$, and PC4-A negatively with the silt percentage. Detailed data on the abiotic environment are shown in Castillo et al. (2014).

\section{Tussock traits}

Tussock architecture traits (Fig. 1) and biomass production and allocation data (Fig. 2) varied widely among measured plants from field populations. Five factors were obtained for the tussock traits in the field from the PCA, explaining $77.7 \%$ of the variance (Table 1; Fig. 3). The first factor (PC1-T) was positively correlated with above-ground biomass (AGB) (marked by live leaf and live shoot biomass, which varied between $1972 \pm 298 \mathrm{~g} \mathrm{~m}^{-2}$ for Mad River and $6866 \pm 622 \mathrm{~g} \mathrm{~m}^{-2}$ for Vancouver Island), LAI (varying between $0.36 \pm 0.04$ for Grays Harbor and $2.49 \pm 0.31$ for Vancouver Island) and root biomass (varying between $512 \pm 81 \mathrm{~g} \mathrm{~m}^{-2}$ for Mad River and $1228 \pm 127 \mathrm{~g} \mathrm{~m}^{-2}$ for Vancouver Island) (Table 1 ; Fig. 3). Above-ground biomass increased with live shoot density ( $\mathrm{r}=0.442, P<0.001, \mathrm{n}=50)$ and leaf area index (LAI) $(\mathrm{r}=0.824, P<0.0001, \mathrm{n}=50)$ and decreased with the number of live leaves $(\mathrm{r}=-0.461, \quad P<0.001, \quad \mathrm{n}=50)$. Above-ground biomass also increased with root biomass $(\mathrm{r}=$ 0.656, $P<0.0001, \mathrm{n}=50$ ).

The second factor (PC2- T) was positively correlated with rhizome biomass, dead shoot biomass, BGB (varying between $1617 \pm 255 \mathrm{~g} \mathrm{~m}^{-2}$ for Grays Harbor and $3678 \pm 946 \mathrm{~g} \mathrm{~m}^{-2}$ for Humboldt Bay) and AGB:BGB ratio (Fig. 3). The third (PC3-T) was positively correlated with live shoot diameter (varying slightly between $3.1 \pm 0.1 \mathrm{~mm}$ for Grays Harbor and Humboldt Bay and $3.4 \pm 0.1$ for Vancouver Island) and height (varying markedly between $29.4 \pm 2.0 \mathrm{~cm}$ for Grays Harbor and $46.4 \pm 1.9 \mathrm{~cm}$ for Vancouver Island), and the fourth (PC4-T) positively with rhizome TNC (changing between $83 \pm 8 \mathrm{mg} \mathrm{g}^{-1}$ DW for Mad River population and $141 \pm 9 \mathrm{mg} \mathrm{g}^{-1}$ DW for Humboldt Bay population; ANOVA, $\left.\mathrm{F}_{4,45}=3.857, P<0.01\right)$ and spiked shoot density (Figs. 1, 2, 3; Table 1).

Each tussock trait showed significant inter-population differences in the field. Nearly all of these interpopulation differences disappeared in the common garden experiment. Just two interpopulation differences were recorded in the common garden experiment, without showing any common behavior with data recorded in the field. Live shoot density of plants from San Francisco Bay was lower than from Grays Harbor and spiked shoot density was higher for San Francisco Bay than for the other populations (ANOVA or Kruskal-Wallis $H$-test, $P<0.05$; Figs. 1, 2).

Relationships between environmental factors and tussock traits

PC1 for tussock traits (PC1-T) correlated positively with PC1-A and PC3-A (Table 2). Thus, tussocks accumulating more roots, more AGB and with higher LAI were growing on coarser sediments at higher latitudes with higher air temperatures during summer (Figs. 4, 5).

PC2-T decreased with PC1-A and increased with PC4-A (Table 2), reflecting that tussocks with higher BGB (marked by higher rhizome biomass) were growing in more finely-textured sediments at higher latitudes, influenced mainly by more growing degree days (Fig. 4).

PC3-T decreased with PC2-A, reflecting that live shoot diameter and height increased in more oxygenated and less acidic sediments exposed at lower 


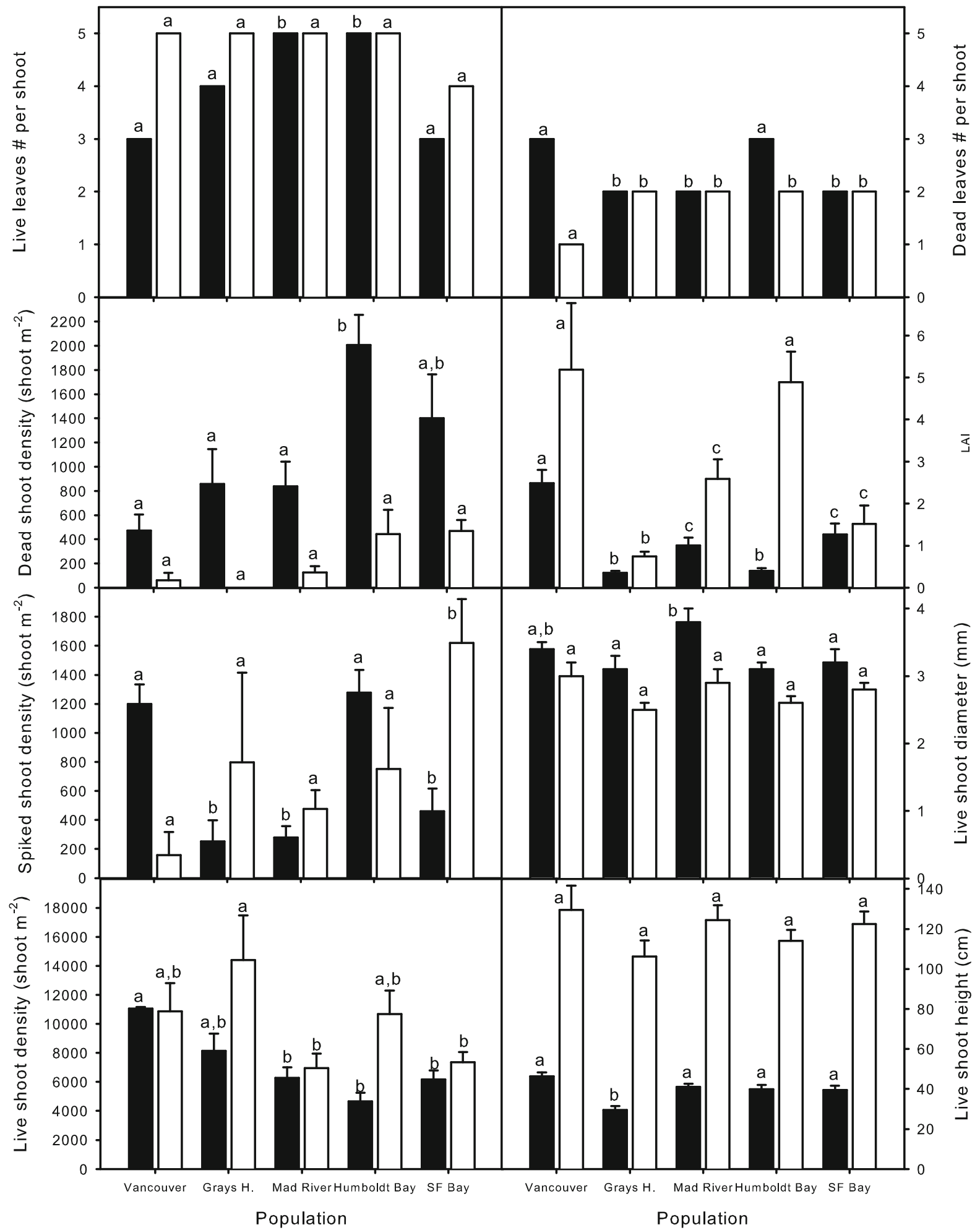


4Fig. 1 Live, spiked and dead shoot density $\left(\right.$ shoot $\mathrm{m}^{-2}$ ), live shoot height $(\mathrm{cm})$, live shoot diameter $(\mathrm{mm})$, number of live and dead leaf per live shoot, and leaf area index (LAI) for five Spartina densiflora invasive populations from five locations along the Pacific Coast of North America (Vancouver Island, Grays Harbor, Mad River, Humboldt Bay, San Francisco Bay) growing in the field (black bars) and in a common garden experiment (white bars). Data are mean $\pm \operatorname{SEM}(N=10)$. Different letters indicate significant differences between populations in the field or in the common garden experiment (ANOVA and Tukey-HSD test or Kruskal-Wallis H-test and Mann-Whitney test, $P<0.05$ )

mean tidal ranges and more mean daily isolation, and PC4-T correlated positively with PC2-A and slightly with PC3-A $(P<0.05)$, showing that rhizomes with higher total nonstructural carbohydrates (TNC) and higher spiked shoot densities were recorded at saltier, more anoxic and acidic sediments exposed to higher air temperature and insolation during summer (Fig. 6; Table 2).

\section{Discussion}

The South American cordgrass Spartina densiflora has invaded habitats with a wide range of environmental conditions along the Pacific Coast of North America. Our results show that the architectural traits of clonal tussocks from these invasive populations are phenotypically plastic in their response to widely variable climate (specifically, air temperature and the duration of the growing season) and substrate conditions (specifically, texture and hypoxia), which suggests that they have the ability to continue to adjust with future climate changes.

The production and allocation of biomass recorded for $S$. densiflora were in the range reported previously for this and other Spartina species (Castillo et al. 2010). Root biomass increased in coarser sediments, whereas rhizomes were more abundant in finer sediments. These results are consistent with previous studies reporting higher root development in order to exploit more soil volume for nutrients in coarsetextured and poor sediments than in fine-textured and fertile sediments (e.g. Wang et al. 2014). Similar tradeoffs between Spartina organs have been described previously between rhizomes, aboveground biomass (AGB) and seed production (e.g. Verburg and Grava 1998; Wang et al. 2008). In addition, root biomass increased with summer air temperature and rhizome biomass increased with the duration of the growing season (the number of growing degree days). Generally speaking, roots in grass species have high turnover rates (e.g. Xiong and Katterer 2010) and are therefore sensitive to shortterm environmental changes such as increases in temperature during summer. In contrast, rhizomes are long-lived structures that would be influenced mainly by long-term stable environmental conditions such as the duration of the growing season. Root biomass of opportunistic invasive species, such as $S$. densiflora, can increase with temperature due to increasing soil nutrient availability through accelerated microbial activity (Thakur et al. 2014). Daleo and Iribarne (2009) reported that $S$. densiflora shows a high plasticity in its root system development between anoxic and well-aerated sediments, allocating most of its root biomass to the first centimeters of soil in anoxic sediments and showing a root biomass more homogeneously distributed in oxygenated soils. In our study, rhizome biomass was around two times higher, and AGB:BGB ratio was almost two times lower, at lower than at higher latitudes, probably due to longer growing seasons that allowed higher carbohydrates reserve accumulation to counter harsh conditions in the salt marshes. This result contrasts with previous studies that found higher allocation to storage organs in dicot species with northward range expansions (Jia et al. 2010; Sawada et al. 1994), but it is in accordance with D'Hertefeldt et al. (2014) who showed that Aegopodium podagraria, a clonal herb with a high phenotypic plasticity, accumulates more rhizomes at lower latitudes. Total nonstructural carbohydrates (TNC) concentrations in rhizomes decreased with lower salinities (lower electrical conductivities), which could reflect the depletion of rhizome reserves due to growth stimulation under brackish conditions, where $S$. densiflora has been described as a highly competitive species (Costa et al. 2003). Depletion of carbohydrate reserves during rapid growth has been reported in several other submersed and emergent aquatic plants such as Phragmites australis (Granéli et al. 1992; Čižková et al. 2001), Egeria densa (Pennington and Sytsma 2009), and Myriophyllum spicatum (Perkins and Sytsma 1987; Madsen 1997). Rhizome dynamics are very important in salt marsh development in a changing world since rhizome accumulation is key to maintaining soil volume with 


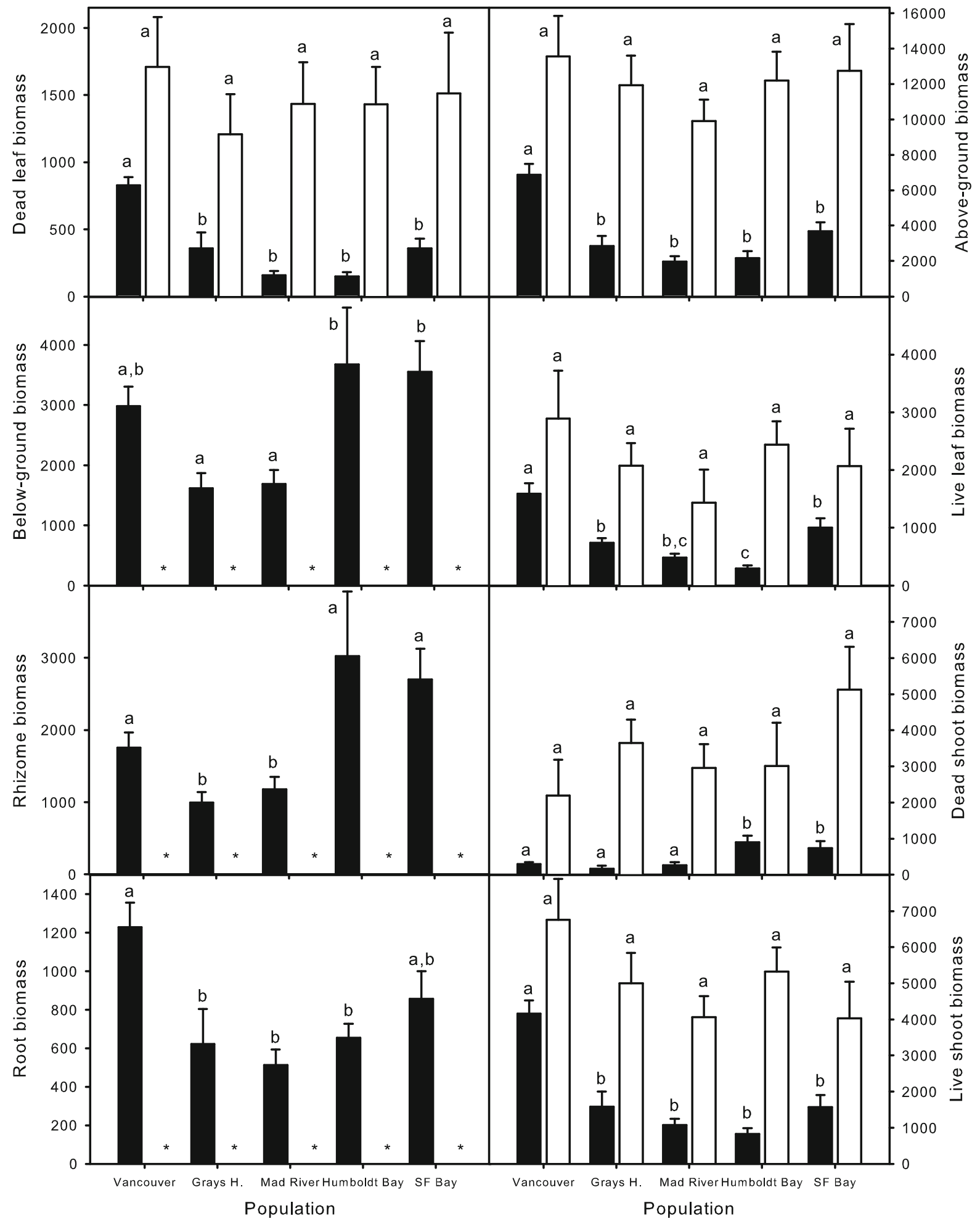


४Fig. 2 Biomass of root, rhizome, below-ground organs, live and dead shoot, live and dead leaf and above-ground organs $\left(\mathrm{g} \mathrm{m}^{-2}\right)$ for five Spartina densiflora invasive populations from five locations along the Pacific Coast of North America (Vancouver Island, Grays Harbor, Mad River, Humboldt Bay, San Francisco Bay) growing in the field (black bars) and in a common garden experiment (white bars). Data are mean \pm $\operatorname{SEM}(N=10)$. Different letters indicate significant differences between populations in the field or in the common garden experiment (ANOVA and Tukey-HSD test, $P<0.05$ ). *Not recorded

increasing sea level rise (Wigand et al. 2014) and because investment of resources in rhizomes contributes to the ability of invasive clonal plants to establish in a wide range of habitats (Price et al. 2001).

Above-ground biomass and leaf area index (LAI) of S. densiflora increased with temperature during summer. The highest values of AGB (primarily biomass of live shoots and leaves) and LAI were recorded for the Vancouver Island population, the most northern location, but, interestingly, the location with the warmest summer temperatures. Low temperatures should constrain C-4 photosynthetic metabolism of S. densiflora since phosphoenolpyruvate carboxylase activity is reduced at lower temperatures (Lara et al. 2001). Previous studies on Spartina species have described a relationship between biomass production and air temperature (Giurgevich and Dunn 1979; Drake 1989; Duarte et al. 2013). On the other hand, AGB increased together with root biomass, which could reflect a higher nutrient uptake favoring aerial biomass production. Biomass production of grasses depends mainly on three structural characters: blade size, shoot density and number of green leaves per tiller (Lemaire and Chapman 1996). In the case of $S$. densiflora along the broad range of latitude represented by our study sites, AGB increased in those populations with higher shoot densities and higher LAI (marked by fewer but larger leaves).

Our results are similar to those recorded along the Atlantic Southwest Coast of South America, where $S$. densiflora is native and its AGB is reduced by climatic restrictions (Montemayor et al. 2014). Nevertheless, $S$. densiflora $\mathrm{AGB}$ in its native range is inversely correlated with latitude since xeric conditions and salinity increase at higher latitudes (Isacch et al. 2006; Montemayor et al. 2014), and the population at the highest latitude in our study had the highest AGB and salinity did not have a significant relationship with AGB. Humid climatic conditions dominated at our high latitude site on Vancouver Island, and no hypersaline conditions were recorded. S. densiflora is a halophyte with a high tolerance to salinity (Maricle et al. 2007), but its growth is limited in
Table 1 Factor loadings (PC-T) of the individual variables obtained by a principal component analysis (PCA) on Spartina densiflora tussocks traits from 5 populations along the West Coast of North America from San Francisco Bay to Vancouver Island

Correlations between the PCA and leaf traits with factor loadings $> \pm 0.600$ are marked in bold

\begin{tabular}{lcccc}
\hline & PC1-T & PC2-T & PC3-T & PC4-T \\
\hline Above-ground biomass & $\mathbf{+ 0 . 9 7 2}$ & +0.063 & -0.091 & -0.036 \\
Live shoot biomass & $\mathbf{+ 0 . 9 6 3}$ & -0.140 & -0.029 & +0.009 \\
Live leaf biomass & $\mathbf{+ 0 . 9 4 2}$ & -0.035 & -0.085 & -0.114 \\
Dead leaf mass & $\mathbf{+ 0 . 8 8 9}$ & -0.144 & -0.090 & +0.017 \\
Leaf area index & $\mathbf{+ 0 . 8 7 6}$ & +0.026 & +0.126 & -0.169 \\
Root biomass & $\mathbf{+ 0 . 7 2 4}$ & +0.268 & +0.127 & -0.232 \\
Live shoot density & +0.527 & -0.297 & -0.314 & +0.086 \\
AGB:BGB ratio & +0.466 & $-\mathbf{0 . 6 1 3}$ & -0.341 & +0.193 \\
Below-ground biomass & +0.365 & $\mathbf{+ 0 . 8 8 8}$ & -0.051 & -0.058 \\
Live shoot height & +0.324 & +0.170 & $\mathbf{+ 0 . 7 5 6}$ & +0.132 \\
Spiked shoot density & +0.312 & +0.259 & +0.452 & $\mathbf{+ 0 . 6 6 6}$ \\
Rhizome biomass & +0.204 & $\mathbf{+ 0 . 9 2 1}$ & -0.093 & -0.049 \\
Rhizome TNC & +0.174 & -0.015 & +0.003 & $\mathbf{+ 0 . 7 8 3}$ \\
Live shoot diameter & -0.021 & -0.253 & $\mathbf{+ 0 . 6 9 5}$ & -0.338 \\
Dead shoot mass & -0.075 & $\mathbf{+ 0 . 8 6 1}$ & -0.181 & -0.074 \\
Dead shoot density & -0.218 & +0.581 & -0.235 & +0.247 \\
Eigen values & 5.797 & 3.458 & 1.629 & 1.410 \\
Explained variance & 36.2 & 21.61 & 10.2 & 8.8 \\
\hline
\end{tabular}




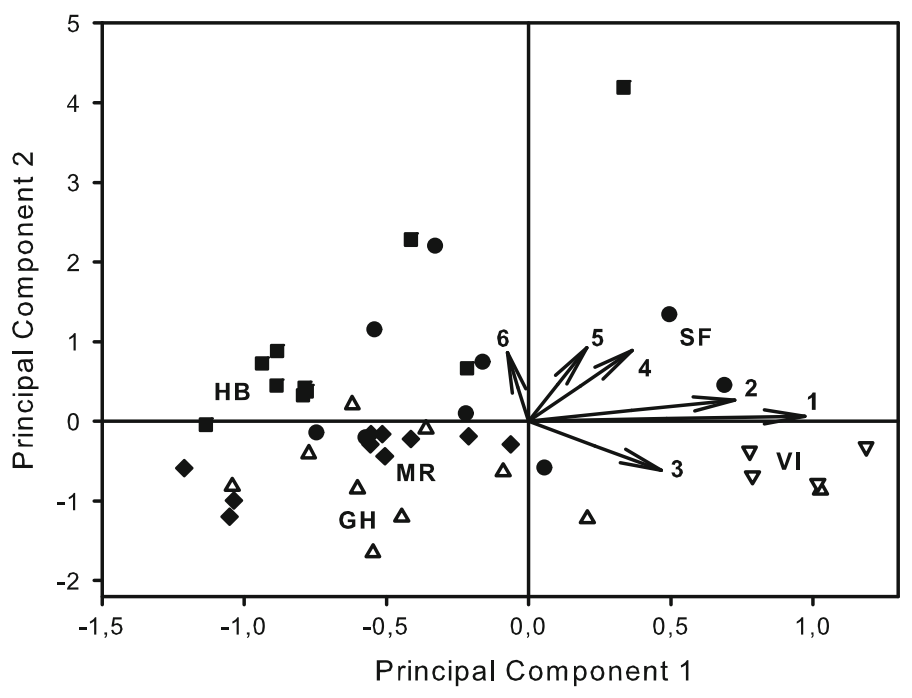

Fig. 3 Principal Components Analysis (PCA) plot of tussock traits in five Spartina densiflora invasive populations along the Pacific Coast of North America (open inverted triangle Vancouver Island, open triangle Grays Harbor, filled diamond

Table 2 Correlation matrix [Pearson correlation coefficient $(\mathrm{r})$ and probability level $(P)]$ between factors loadings coming from Principal Components Analyses for abiotic environmental variables (PC-A) and for tussocks traits (PC-T) for five Spartina densiflora invasive populations along the Pacific Coast of North America $(N=50)$

\begin{tabular}{ccrrr}
\hline & PC1-A & PC2-A & PC3-A & PC4-A \\
\hline PC1-T & & & & \\
$r=$ & $\mathbf{+ 0 . 5 6 6}$ & -0.204 & $\mathbf{+ 0 . 5 5 5}$ & +0.047 \\
$P<$ & $\mathbf{0 . 0 0 0 1}$ & 0.155 & $\mathbf{0 . 0 0 0 1}$ & 0.747 \\
PC2-T & & & & \\
$r=$ & $-\mathbf{0 . 4 7 2}$ & -0.108 & +0.201 & $+\mathbf{0 . 4 5 7}$ \\
$P<$ & $\mathbf{0 . 0 0 0 1}$ & 0.454 & 0.163 & $\mathbf{0 . 0 0 1}$ \\
PC3-T & & & & \\
$r=$ & +0.060 & $-\mathbf{0 . 3 9 3}$ & +0.115 & +0.066 \\
$P<$ & 0.677 & $\mathbf{0 . 0 0 5}$ & 0.427 & 0.648 \\
PC4-T & & & & \\
$r=$ & -0.223 & $\mathbf{+ 0 . 3 9 3}$ & $\mathbf{+ 0 . 3 5 4}$ & +0.174 \\
$P<$ & 0.120 & $\mathbf{0 . 0 0 5}$ & $\mathbf{0 . 0 1 2}$ & 0.227 \\
\hline
\end{tabular}

Correlations with $P<0.05$ are marked in bold

hypersaline conditions (Castillo et al. 2005b). As in our study, salinity was not directly related to biomass accumulation of Spartina maritima along a latitude gradient in Portugal (Duarte et al. 2013). The leaves of S. densiflora at Vancouver Island were at a suboptimal state with low photosynthetic pigments concentrations
Mad River, filled square Humboldt Bay, filled circle San Francisco Bay). Vectors: 1 Above-ground biomass, 2 Root biomass, 3 Above: below-ground biomass ratio, 4 Belowground biomass, 5 Rhizome biomass, 6 Dead shoot biomass

(Castillo et al. 2014) that could compensate with functional tussock traits such as higher LAI and higher tiller densities leading to higher AGB accumulation. In view of these results, it is expected that $S$. densiflora invasion would be faster at Vancouver Island where summers are mild in comparison to the other invaded estuaries to the South.

More robust (taller and wider) shoots were found growing on more oxygenated sediments. Previous studies have described $S$. densiflora as a halophyte whose germination, distribution, physiology and biomass are limited by anoxia along the tidal gradient (Castillo et al. 2000, 2008; Mateos-Naranjo et al. 2008; Abbas et al. 2012, 2014; Di Bella et al. 2014). This behavior contrasts with that of halophytes that are well-adapted to low marsh conditions, such as Spartina maritima (Curtis) Fernald, which increased its shoot height through phenotypic plasticity when growing on anoxic sediments (Castillo et al. 2005a).

Every population converged in almost all tussock architecture traits when growing in a common environment, suggesting that environmental conditions and phenotypic plasticity largely determine tussock traits in S. densiflora on the Pacific Coast of North America. These $S$. densiflora populations also have high phenotypic plasticity in leaf traits (Castillo et al. 2014), and to increasing salinity that can be expected with increased global warming and sea level rise 


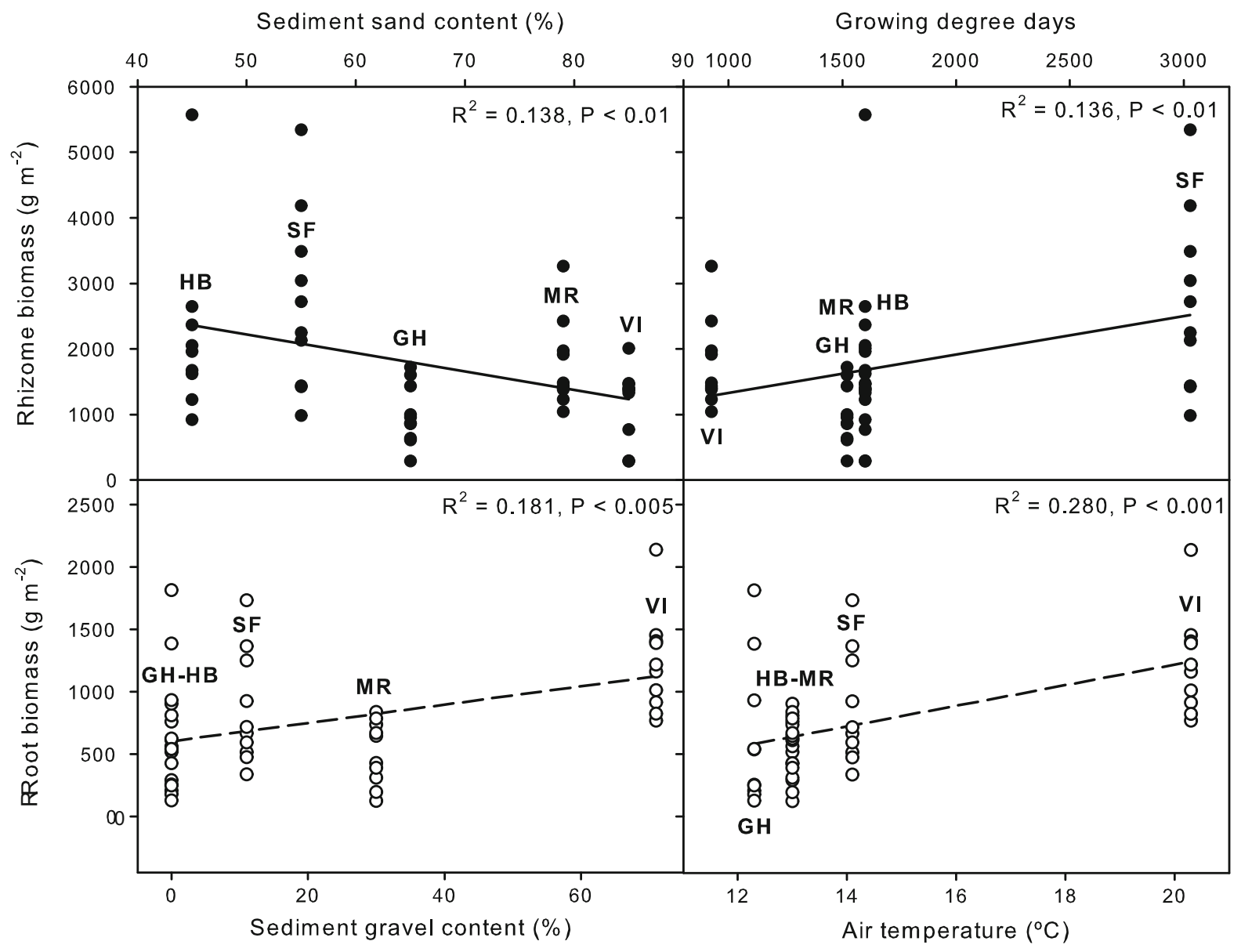

Fig. 4 Relationships between rhizome biomass and sediment sand content and growing degree days, and between root biomass and sediment gravel content and mean daily air temperature during last week before sampling for tussocks from

(Grewell et al. 2015, this issue). Abbas et al. (2012) also reported high physiological plasticity for $S$. densiflora seedlings in response to flooding. The considerable phenotypic plasticity in $S$. densiflora is consistent with that found in S. anglica (Thompson et al. 1991), S. foliosa (Trnka and Zedler 2000) and $S$. alterniflora (Elsey-Quirk et al. 2011). High phenotypic plasticity would allow $S$. densiflora to adjust important functional traits in response to variable environmental conditions, resulting in the ability to invade diverse habitats, a trait that has also been described for other invasive plants (e.g. Williams et al. 1995). Recent observations confirm that the invasive spread of S. densiflora in the Pacific Northwest region five invasive populations of Spartina densiflora along the Pacific Coast of North America. Populations: SF San Francisco Bay Estuary, $H B$ Humboldt Bay Estuary, $M R$ Mad River Estuary, GH Grays Harbor Estuary, VI Vancouver Island

of North America accelerated during the last two decades (e.g. Pickart 2001; Smith et al. 2001). These results are consistent with those recorded on the southwest Iberian Peninsula, where S. densiflora has invaded very different estuarine habitats (Nieva et al. 2001b), and a variety of phenotypes are recognized (Castillo et al. 2003; Nieva et al. 2005; Castillo et al. 2008).

In contrast to our results, Qing et al. (2011) reported differences in plant traits in a common garden experiment comparing native North American populations of $S$. alterniflora and invasive populations in China. This is perhaps due to genetic shifts that can play a vital role in the success of invasions. Our results 


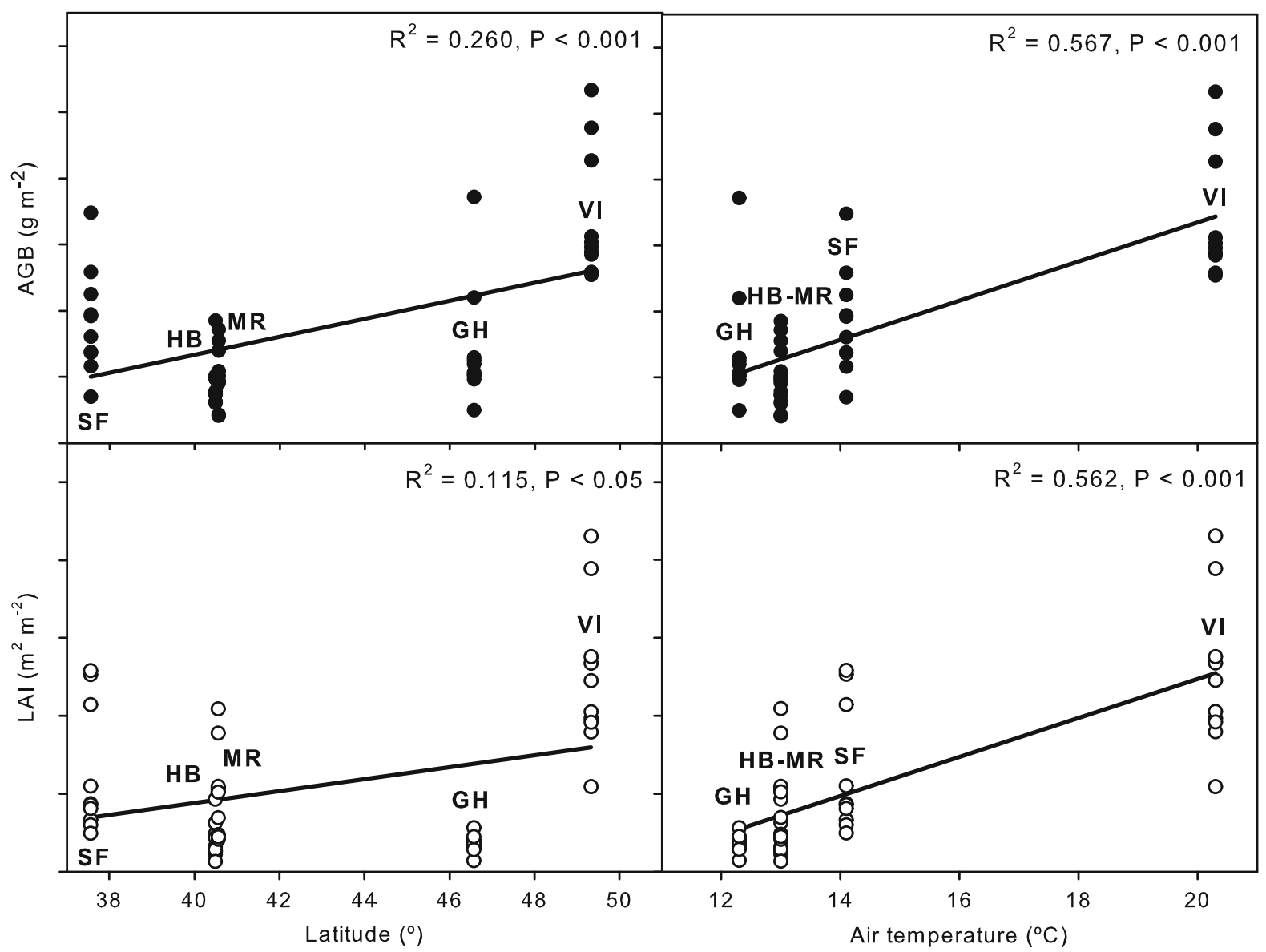

Fig. 5 Relationship between above-ground biomass (AGB) and leaf area index (LAI) and sediment gravel content, latitude and mean daily air temperature during last week before sampling for tussocks from five invasive populations of Spartina

point to a relatively low level of genetic variation for tussock architecture traits in invasive $S$. densiflora populations. This result is consistent with previous studies that recorded high genetic similarity between S. densiflora invasive populations (Ayres et al. 2008), which may be the result of genetic drift in genotypes introduced sequentially from one estuary to another. A genetic component influencing these traits due to local adaptation cannot be ruled out, however, since we found slight significant interpopulation differences in live and spiked shoot density after more than 2 year in a common environment. Furthermore, our common garden experiment may not necessarily have provided conditions for different genotypes to express distinct tussock-trait phenotypes (Thompson 1991).

densiflora along the Pacific Coast of North America. Populations: $S F$ San Francisco Bay Estuary, $H B$ Humboldt Bay Estuary, $M R$ Mad River Estuary, GH Grays Harbor Estuary, VI Vancouver Island

In view of these results and those of companion studies (Castillo et al. 2014; Grewell et al. 2015), $S$. densiflora appears to be a halophyte with a high degree of phenotypic plasticity in tussock architecture and foliar traits that enables it to colonize a wide range of environmental variability in novel marsh habitats along the Pacific Coast of North America. Furthermore, our data support predictions (Bortolus 2006) that S. densiflora has the capacity to adjust and invade European salt marshes at higher latitudes than it currently occupies on the southwest of the Iberian Peninsula. S. densiflora appears to have the capacity to respond successfully to changes in the abiotic conditions of salt marshes driven by global climate change, such as increasing air temperature and estuarine salinity. 


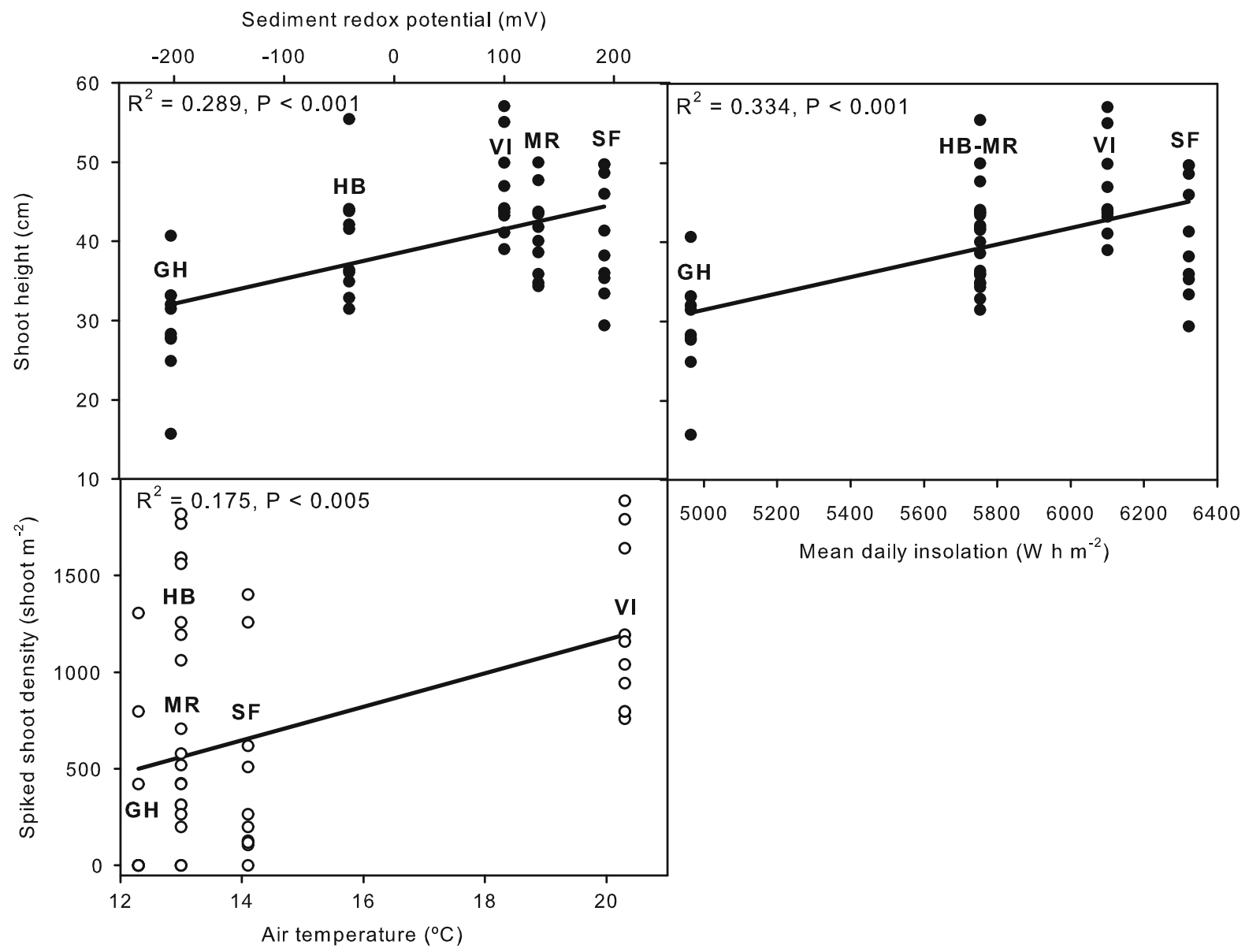

Fig. 6 Relationship between shoot height and sediment redox potential and mean daily global insolation for the sampling month, and between spiked shoot density and mean daily air temperature during last week before sampling for tussocks from

Acknowledgments The authors thank D. Kerr, N. Mikkelsen and Ch. van Ossenbruggen for their assistance in the field. Thanks to M. Moscow, C. J. Futrell, J. Grant, R. Miller, S. Wells and C. Peña for their help in the laboratory. We are also grateful to the California Department of Food and Agriculture, Oregon Department of Agriculture, Washington State Department of Agriculture, Vancouver Island Conservation Land Management Program and Ducks Unlimited Canada for their assistance. Jesús M. Castillo thanks to the Spanish Ministry of Education, Culture and Sport for a grant of staff mobility for university teachers.

\section{References}

Abbas AM, Rubio-Casal AE, de Cires A, Figueroa E, Lambert AM, Castillo JM (2012) Effects of flooding on germination and establishment of the invasive cordgrass Spartina densiflora. Weed Res 52:269-276. doi:10.1111/j.1365-3180. 2012.00913.x five invasive populations of Spartina densiflora along the Pacific Coast of North America. Populations: SF San Francisco Bay Estuary, $H B$ Humboldt Bay Estuary, $M R$ Mad River Estuary, GH Grays Harbor Estuary, VI Vancouver Island (Baynes Sound)

Abbas AM, Rubio-Casal AE, de Cires A, Figueroa E, Nieva JJ, Castillo JM (2014) Wrack burial reduces germination and establishment of the invasive cordgrass Spartina densiflora. Neobiota 21:65-79. doi:10.3897/neobiota.21.4963

Álvarez R, Mateos-Naranjo E, Gandullo J, Rubio-Casal AE, Moreno FJ, Figueroa ME, Castillo JM (2009) Ecotypic variations in PEPC activity of the cordgrass Spartina densiflora through its latitudinal distribution range. Plant Biol 12:154-160. doi:10.1111/j.1438-8677.2009.00198.x

Ayres DR, Grotkopp E, Zaremba K, Sloop CM, Blum MJ, Bailey JP, Anttila CK, Strong DR (2008) Hybridization between invasive Spartina densiflora (Poaceae) and native S. foliosa in San Francisco Bay, California, USA. Am J Bot 95:713-719. doi:10.3732/ajb.2007358

Bortolus A (2006) The austral cordgrass Spartina densiflora Brong.: its taxonomy, biogeography and natural history. J Biogeogr 33:158-168. doi:10.1111/j.1365-2699.2005.01380.x

Carrión-Tacuri J, Rubio-Casal AE, de Cires A, Figueroa ME, Castillo JM (2011) Lantana camara L.: a weed with a great 
light-acclimation capacity. Photosynthetica 49:321-329. doi:10.1007/s11099-011-0039-6

Castillo JM, Fernández-Baco L, Castellanos EM, Luque CJ, Figueroa ME, Davy AJ (2000) Lower limits of Spartina densiflora and $S$. maritima in a Mediterranean salt marsh determined by differential ecophysiological tolerances. J Ecol 88:801-812. doi:10.1046/j.1365-2745.2000.00492. $\mathrm{x}$

Castillo JM, Rubio-Casal AE, Luque T, Figueroa ME, Nieva FJ (2003) Intratussock tiller distribution and biomass of Spartina densiflora Brongn. in an invaded salt marsh. Lagascalia 23:61-73

Castillo JM, Redondo S, Wharmby C, Luque T, Figueroa ME (2005a) Environmental determination of shoot height in populations of the cordgrass Spartina maritima. Estuaries 28:761-766. doi:10.1007/BF02732913

Castillo JM, Rubio-Casal AE, Redondo S, Álvarez-López AA, Luque T, Luque C, Nieva FJ, Castellanos EM, Figueroa ME (2005b) Short-term responses to salinity of an invasive cordgrass. Biol Invasions 7:29-35. doi:10.1007/1-40203870-4_4

Castillo JM, Mateos-Naranjo E, Nieva FJ, Figueroa ME (2008) Plant zonation at salt marshes of the endangered cordgrass Spartina maritima invaded by Spartina densiflora. Hydrobiologia 614:363-371. doi:10.1007/s10750-0089520-z

Castillo JM, Rubio-Casal AE, Figueroa E (2010) Cordgrass biomass in coastal marshes. In: Momba M, Bux F (eds) biomass. Sciyo, Croatia, pp 1-26

Castillo JM, Grewell BJ, Pickart A, Bortolus A, Peña C, Figueroa E, Sytsma M (2014) Phenotypic plasticity of invasive Spartina densiflora (Poaceae) along the Pacific Coast of North America. Am J Bot 101:1-11. doi:10.3732/ajb. 1400014

Čižková H, Istvánovics V, Bauer V, Balázs L (2001) Low levels of reserve carbohydrates in reed (Phragmites australis) stands of Kis-Balaton, Hungary. Aquat Bot 69:209-216. doi:10.1016/S0304-3770(01)00139-5

Costa CSB, Marangoni JC, Azevedo AMG (2003) Plant zonation in irregularly flooded salt marshes: the relative importance of stress tolerance and biological interactions. J Ecol 91:951-965. doi:10.1046/j.1365-2745.2003.00821.x

Daehler CC, Strong D (1996) Status, prediction and prevention of introduced cordgrass Spartina spp. invasions in Pacific estuaries, USA. Biol Conserv 78:51-58. doi:10.1016/00063207(96)00017-1

Daleo P, Iribarne O (2009) The burrowing crab Neohelice granulata affects the root strategies of the cordgrass Spartina densiflora in SW Atlantic salt marshes. J Exp Mar Biol Ecol 373:66-71. doi:10.1016/j.jembe.2009.03.005

De Frenne P, Graae BJ, Rodríguez-Sánchez F, Kolb A, Chabrerie O, Decocq G, De Kort H et al (2013) Latitudinal gradients as natural laboratories to infer species' responses to temperature. J Ecol 101:784-795. doi:10.1111/13652745.12074

D’Hertefeldt T, Eneström JM, Pettersson LB (2014) Geographic and habitat origin influence biomass production and storage translocation in the clonal plant Aegopodium podagraria. PLoS ONE 9:e85407. doi:10.1371/journal.pone. 0085407
Di Bella CE, Striker GG, Escaray FJ, Lattanzi FA, Rodriguez AM, Grimoldi AA (2014) Saline tidal flooding effects on Spartina densiflora plants from different positions of the salt marsh. Diversities and similarities on growth, anatomical and physiological responses. Environ Exp Bot 102:27-36. doi:10.1016/j.envexpbot.2014.02.009

Drake BG (1989) Photosynthesis of salt marsh species. Aquat Bot 34:167-1180. doi:10.1016/0304-3770(89)90055-7

Drenovsky RD, Grewell BJ, D’Antonio CM, Funk JL, James JJ, Molinari N, Parker IM, Richards CL (2012) A functional trait perspective on plant invasion. Ann Bot 110:141-153. doi:10.1093/aob/mcs 100

Duarte B, Couto T, Freitas J, Valentim J, Silva H, Marques JC, Dias JM, Caçador I (2013) Abiotic modulation of Spartina maritima photobiology in different latitudinal populations. Estuar Coast Shelf Sci 130:127-137. doi:10.1016/j.ecss. 2013.02.008

Elsey-Quirk T, Seliskar DM, Gallagher JL (2011) Differential population response of allocation, phenology, and tissue chemistry in Spartina alterniflora. Plant Ecol 212:18731885. doi:10.1007/s11258-011-9960-9

Environment Canada (2002) Canadian Climate Normals, 1971-2000. http://www.climate.weatheroffice.ec.gc.ca/ climate_normals. Accessed 28 December 2014

Epstein E (1972) Mineral nutrition of plants. Principles and perspectives. Wiley, New York

Federal Geographic Data Committee (2012) Coastal and Marine Ecological Classification Standard. Marine and Coastal Spatial Data Subcommittee. FGDC-STD-018-2012. U.S. Department of the Interior, Washington, DC

Fortune PM, Schierenbeck K, Ayres D, Bortolus A, Catrice O, Brown S, Ainouche ML (2008) The enigmatic invasive Spartina densiflora: a history of hybridizations in a polyploidy context. Mol Ecol 17:4304-4316. doi:10.1111/j. 1365-294X.2008.03916.x

Gee GW, Bauder JW (1986) Particle-size analysis. In: Page AL (ed) Methods of Soil Analysis, Part 1, Physical and Mineralogical Methods. Agronomy Monograph 9. American Society of Agronomy, Madison, pp 383-411

Gioria M, Osborne BA (2014) Resource competition in plant invasions: emerging patterns and research needs. Front Plant Sci. doi:10.3389/fpls.2014.00501

Giurgevich JR, Dunn EL (1979) Seasonal patterns of CO2 and water vapor exchange of the tall and short height forms of Spartina alterniflora Loisel in a Georgia salt marsh. Oecologia 43:139-156. doi:10.1007/BF00344767

Granéli W, Weisner SEB, Sytsma MD (1992) Rhizome dynamics and resource storage in Phragmites australis. Wetlands Ecol Manage 1:239-247

Grewell BJ, Castillo JM, Skaer Thomason MJ, Drenovsky RE (2015) Phenotypic plasticity and population differentiation in response to salinity in the invasive cordgrass Spartina densiflora. In review: Biol Invasions (this issue)

Hierro JL, Maron JL, Callaway R (2005) A biogeographical approach to plant invasions: the importance of studying exotics in their introduced and native range. $\mathrm{J}$ Ecol 93:5-15. doi:10.1111/j.0022-0477.2004.00953.x

Hoagland DR, Arnon DI (1950) The water-culture method for growing plants without soil. Calif Agric Exp Station Circ $347: 4-32$ 
Howard VH, Sytsma MD (2013) Potential ocean dispersal of cordgrass (Spartina spp.) from core infestations. Invas Plant Sci Mana 6:250-259. doi:10.1614/IPSM-D-1200042.1

Isacch JP, Costa CSB, Rodriguez-Gallego L, Conde D, Escapa M, Gagliardini DA, Iribarne OO (2006) Distribution of saltmarsh plant communities associated with environmental factors along a latitudinal gradient on the southwest Atlantic coast. J Biogeogr 33:888-900. doi:10.1111/j. 1365-2699.2006.01461.x

Jia X, Pan XY, Sosa A, Li B, Chen JK (2010) Differentiation in growth and biomass allocation among three native Alternanthera philoxeroides varieties from Argentina. Plant Spec Biol 25:85-92. doi:10.1111/j.1442-1984.2010. 00271.x

Kirwan ML, Gunterspergen GR, Morris J (2009) Latitudinal trends in Spartina alterniflora productivity and the response of coastal marshes to global change. Global Change Biol 15:1982-1989. doi:10.1111/j.1365-2486. 2008.01834.x

Lammi J (2008) Online-photoperiod calculator. http://www.sci. fi/ benefon/sol.html. Accessed 20 December 2014

Lara MV, Casati P, Andreo CS (2001) In vivo phosphorylation of phosphoenolpyruvate carboxylase in Egeria densa, a submersed aquatic species. Plant Cell Physiol 42:441-445

Lemaire G, Chapman D (1996) Tissue flows in grazed plant communities. In: Hodgson J, Illius AW (eds) The ecology and management of grazing systems. CAB International, Wallingford, pp 3-36

Madsen JD (1997) Seasonal biomass and carbohydrate allocation in a southern population of Eurasian watermilfoil. J Aquat Plant Manage 35:15-21

Maricle BR, Lee RW, Hellquist CE, Kiirats O, Edwards GE (2007) Effects of salinity on chlorophyll fluorescence and $\mathrm{CO}_{2}$ fixation in $\mathrm{C} 4$ estuarine grasses. Photosynthetica 45:433-440. doi:10.1007/s11099-007-0072-7

Martina JP, von Ende CN (2013) Increased spatial dominance in high nitrogen, saturated soil due to clonal architecture plasticity of the invasive wetland plant, Phalaris arundinacea. Plant Ecol 214:1443-1453. doi:10.1007/s11258013-0265-z

Mateos-Naranjo E, Redondo-Gómez S, Luque CJ, Castellanos EM, Davy AJ, Figueroa ME (2008) Environmental limitations on recruitment from seed in invasive Spartina densiflora on a southern European salt marsh. Estuar Coast Shelf Sci 79:727-732. doi:10.1016/j.ecss.2008.06.017

Matesanz S, Gianoli E, Valladares F (2010) Global change and the evolution of phenotypic plasticity in plants. Ann NY Acad Sci 1206:35-55. doi:10.1111/j.1749-6632.2010.05704.x

Montemayor DI, Canepuccia AD, Pascual J, Iribarne OO (2014) Aboveground biomass patterns of dominant Spartina species and their relationship with selected abiotic variables in Argentinean SW Atlantic marshes. Estuar Coast 37:411-420. doi:10.1007/s12237-013-9688-y

Morgan VH, Sytsma M (2010) Alaska Spartina prevention, detection and response plan. https://alaskafisheries.noaa. gov/shorezone/reports/akspartina_plan.pdf. Accessed 28 January 2015

National Climatic Data Center (NCDC) (2004) Climatography of the United States No. 20, Monthly Station Climate
Summaries, 1971-2000. National Oceanic and Atmospheric Administration, Asheville, NC

National Climatic Data Center (NCDC) (2013) http://www. ncdc.noaa.gov/. Accessed 15 November 2014

National Renewable Energy Laboratory (NREL) (1992) National Solar Radiation Database. 30-year averages of monthly solar radiation and illuminance, 1961-1990. National Climatic Data Center, Asheville, NC

Natural Resource Canada (NRC) (2009) Photovoltaic potential and solar resource of Canada. https://glfc.cfsnet.nfis.org/ mapserver/pv/index.php. Accessed 15 November 2014

Nelson N (1944) A photometric adaptation of the Somogyi method for determination of glucose. J Biol Chem 153:375-380

Nieva FJ, Castellanos EM, Figueroa ME (2001a) Effects of light and salinity on seed germination in the marsh invader Spartina densiflora Brong., 1829 (Gramineae) from Gulf of Cadiz-Spain. Boletín de la Real Sociedad Española de Historia Natural 96:117-124

Nieva FJ, Diaz-Espejo A, Castellanos EM, Figueroa ME (2001b) Field variability of invading populations of Spartina densiflora Brong. grown in different habitats of the Odiel marshes (SW Spain). Estuar Coast Shelf S 52:515-552. doi:10.1006/ecss.2000.0750

Nieva FJJ, Castellanos EM, Castillo JM, Figueroa ME (2005) Clonal growth and tiller demography of the invader cordgrass Spartina densiflora Brongn at two contrasting habitats in SW European salt marshes. Wetlands 25:122-129. doi:10.1672/0277-5212(2005)025[0122:CGATDO]2.0.CO;2

Owens CS, Madsen JD (1998) Phenological studies of carbohydrate allocation in Hydrilla. J Aquat Plant Manage 36:40-44

Pennington TG, Sytsma MD (2009) Seasonal changes in carbohydrate and nitrogen concentrations in Oregon and California populations of Brazilian egeria (Egeria densa). Invasive Plant Sci Manag 2:120-129

Perkins MA, Sytsma MD (1987) Harvesting and carbohydrate accumulation in Eurasian watermilfoil. J Aquat Plant Manage 25:57-62

Pfauth M, Sytsma M, Isaacson D (2007) Oregon Spartina response plan. Oregon Department of Agriculture, Portland

Pickart A (2001) The distribution of Spartina densiflora and two rare salt marsh plants in Humboldt Bay 1998-1999. Technical Report. US Fish and Wildlife Service, Humboldt Bay National Wildlife Refuge, Arcata, California

Prati D, Schmid B (2000) Genetic differentiation of life-history traits within populations of the clonal plant Ranunculus reptans. Oikos 90:442-456. doi:10.1034/j.1600-0706. 2000.900303.x

Price EAC, Gamble R, Williams GG, Marshall C (2001) Seasonal patterns of partitioning and remobilization of C-14 in the invasive rhizomatous perennial Japanese knotweed (Fallopia japonica (Houtt.) Ronse Decraene). Evol Ecol 15:347-362. doi:10.1023/A:1016036916017

Qing H, Yao Y, Xiao Y, Hu F, Sun Y, Zhou C, An S (2011) Invasive and native tall forms of Spartina alterniflora respond differently to nitrogen availability. Acta Oecol 37:23-30. doi:10.1016/j.actao.2010.11.002

Roiloa SR, Alpert P, Tharayil N, Hancock G, Bhowmik PC (2007) Greater capacity for division of labour in clones of 
Fragaria chiloensis from patchier habitats. J Ecol 95:397-405. doi:10.1111/j.1365-2745.2007.01216.x

Saarela JM (2012) Taxonomic synopsis of invasive and native Spartina (Poaceae, Chloridoideae) in the Pacific Northwest (British Columbia, Washington and Oregon), including the first report of Spartina $\times$ townsendii for British Columbia, Canada. PhytoKeys 10:25-82. doi:10.3897/phytokeys.10. 2734

Sawada S, Nakajima Y, Tsukuda M, Sasaki K, Hazama Y et al (1994) Ecotypic differentiation of dry-matter production processes in relation to survivorship and reproductive potential in Plantago asiatica populations along climatic gradients. Funct Ecol 8:400-409. doi:10.2307/2389834

Smith D, Klohr S, Zaremba K (2001) San Francisco Bay and beyond: invasive Spartina continues to spread among Pacific estuaries. ANS Digest 4:46-47

Spicher D, Josselyn M (1985) Spartina (Gramineae) in Northern California: distribution and taxonomic notes. Madroño 32:158-167

Swank JC, Below FE, Lambert RJ, Hageman RH (1982) Interaction of carbon and nitrogen metabolism in the productivity of maize. Plant Physiol 70:1185-1190

Thakur MP, Reich PB, Eddy WC, Stefanski A, Rich R, Hobbie SE, Eisenhauer N (2014) Some plants like it warmer: increased growth of three selected invasive plant species in soils with a history of experimental warming. Pedobiologia 57:57-60. doi:10.1016/j.pedobi.2013.12.002
Thompson JD (1991) Phenotypic plasticity as a component of evolutionary change. Trends Ecol Evol 6:246-249. doi:10. 1016/0169-5347(91)90070-E

Trnka S, Zedler JB (2000) Site conditions, not parental phenotype, determine the height of Spartina foliosa. Estuaries 23:572-582. doi: $10.2307 / 1353147$

Verburg R, Grava D (1998) Differences in allocation patterns in clonal and sexual offspring in a woodland pseudo-annual. Oecologia 115:472-477. doi:10.1007/s004420050543

Wang MT, Zhao ZG, Du GZ, He YL (2008) Effects of light on the growth and clonal reproduction of Ligularia virgaurea. J Integr Plant Biol 50:1015-1023. doi:10.1111/j.17447909.2008.00645.x

Wang L, Li L, Chen X, Tian X, Wang X, Luo G (2014) Biomass allocation patterns across China's terrestrial biomes. PLoS ONE 9:1-9. doi:10.1371/journal.pone.0093566

Wigand C, Roman ChT, Davey E, Stolt M, Johnson R, Hanson A et al (2014) Below the disappearing marshes of an urban estuary: historic nitrogen trends and soil structure. Ecol Appl 24:633-649. doi:10.1890/13-0594.1

Williams DG, Mack RN, Black RN (1995) Ecophysiology of introduced Pennisetum setaceum on Hawaii: the role of phenotypic plasticity. Ecol 76:1569-1580. doi:10.2307/1938158

Xiong SJ, Katterer T (2010) Carbon-allocation dynamics in reed canary grass as affected by soil type and fertilization rates in northern Sweden. Acta Agric Scand B-S P 60:24-32. doi:10.1080/09064710802558518 